Reijo Raivola

\title{
Viisi teesiä koulutuksen merkityksestä sivistys-Suomessa
}

\author{
"Koulutus on kaikki kaikessa. \\ Persikka oli muinoin vain karvas manteli. \\ Kukkakaalikaan ei ole muuta kuin kerä- \\ kaali, joka on saanut yliopistokoulutuksen." \\ (Mark Twain)
}

\begin{abstract}
Mark Twain ivasi purevasti jo runsas 100 vuotta sitten katteetonta koulu-uskoa. Kuitenkin vasta toisen maailmansodan jälkeen koulutus tunkeutui jokaisen yksityisyyteen ja laajeni kehittyneiden kansantalouksien suurimmaksi elinkeinohaaraksi. Se perusteli voimavaravaatimuksensa ilmoittamalla investoivansa investoimiseen. ja kaikkiko vain sen takia, että Adam Smithin klassista talousteoriaa sovellettiin aineettomaan hyödykkeeseen: se, mitä tuotannon kasvusta ei voitu laskea lisääntyneen tai tehostuneen fyysisen tuotannontekijän tilille, kirjattiin koulutuksella tuotetun inhimillisen pääoman hyväksi.
\end{abstract}

Tulkinta oli rohkea. Metodologia oli siihen asti opettanut, että ryhmän sisäinen, tilastollisesti selittämättä jäänyt vaihtelu on tulkittava satunnaistekijöistä aiheutuvaksi virhevarianssiksi.

Uusi oppi lankesi kuitenkin otolliseen maaperään. Se avulla voitiin perustella tarpeettomaksi käyneen nuorison sijoittaminen yhteiskunnan rakenteisiin, valmistautuminen työelämään, työn ja koulutuksen liittäminen funktionaalisesti toisiinsa, niin, koko yhteiskunnallinen eriarvoisuus. Uudet yhtälöt näyttivät myös toimivan: kansakunnan koulutusasteen ja bruttokansantuotteen välillä näytti vallitsevan selvä positiivinen korrelaatio, samoin yksilötasolla koulutuksen ja ansioiden välillä. Yksilölle koulutus näytti toimivan ei niin kuin henkivakuutus, vaan niinkuin säästövakuutus, jonka hedelmät sai korjata jo itse eikä vasta jälkeen jäävät edunsaajat. Siitä syystä uusi oppi olikin houkutteleva: se lupasi toisin kuin kirkko pelastuksen jo tässä ajassa.

Sijoitusviisauden levitessä inflaatio alkoi kuitenkin syödä pääomaa. Niin säästövakuutus huomaamatta muuttui vahinkovakuutukseksi, jolla ei enää hankittu etuja, vaan varauduttiin onnettomuuksien varalle. ja yhä useampi sortui houkutukseen polttaa oma talonsa, sortua vakuutuspetokseen käyttämällä koulutuksessa yhteiskunnan rakenteista ja ihmisen käyttäytymisestä saamaansa tietoa oman, lain- tai moraalin vastaiseen eduntavoitteluun.

Koulutuksen ongelmat ja samalla haasteet johtuvat koulutuksen vaihtoarvon (todistusten ja oppiarvojen vaihtaminen työpaikkaan ja sosiaaliseen asemaan) kohtuuttomasta korostumisesta ja koulutusinstituution alisteisesta asemasta yhteiskunnan muihin instituutioihin, ennen kaikkea palkkatyöhön, nähden. Vasta nyt on alettu kysellä koulutuksen käyttöarvon perään. Opetussuunnitelman kattamisen ja sisältöjen tietämisen sijasta vaaditaan osaamista, taitotietoa. Mutta tämä uusi välineellisyyden näkökulma on, jos mahdollista, painanut koulutuksen itseisarvon vieläkin enemmän näkymättömiin. Koulutuksen itseisarvon eli kasvatuksen kunnioittaminen on kuitenkin ehdoton vaatimus, jotta koulutusinstituutio voi suorittaa kulttuurin siirtämis- ja 
kehittämistehtävänsä, toimia elinkeinoelämäninnovoivana voimana, jotta sillä olisi mahdollisuus katsoa tuulilasista suuntaa peruutuspeilin asemesta.

\section{TEESI: Sivistystaso on ratkaisevampi kuin koulutustaso - myös Suomen kansan menestymiselle kansainvälisessä kilpailussa.}

Korkeakoulutuksessa ollaan vetämässä jyrkkää rajaa hyödyllisen empirismin ja pakosta siedettävän humanismin välille. Rajanveto ei ole universaalinen välttämättömyys eikä yliopistohistorian itsensä tekemä erottelu. Kiista on syntynyt, kun tarkasteluun on tuotu tieto-opillinen jako rationalismiin ja idealismiin. Empiirinen metodi yhdistettiin rationalismiin ja humanistinen maailmankuva idealismiin. jako näkyy kaikkialla: koulutusohjelmien sisällöissä, tutkintojen käyttö- ja vaihtoarvossa, tiederajoissa, tutkintojen arvostuksessa ja niillä vaihdetuissa ammateissa.

\section{TEESI: Teknisen ja humanistisen kulttuurin kahtiajaosta päästään irti omaksumalla täydennyskoulutuksessa ristiinkoulutuksen periaate.}

Koulutuksen organisoimisen malli on löydettävissä kahden ääripään väliltä: Teknisen ja luonnontieteellisen peruskoulutuksen saaneet opastetaan tuntemaan se yhteiskunta ja se ihminen, joiden palveluksessa he ovat. Vastaavasti humanistit ja yhteiskuntatieteilijät hankkivat vankan teknis-luonnontieteellisen perussivistyksen.

Ralf Dahrendorf puhuu sodan jälkeistä Eurooppaa hallinneen poliittisen suunnan mukaisesti sosiaalidemokraattisesta konsensuksesta, jossa julkinen valta tunkeutui ihmisen yksityiselle alueelle, yhteiskunnallisti yksityiset tarpeet ja loi mekanismit noiden tarpeiden keskimääräiseksi tyydyttämiseksi. Koulutuksesta tuli keskeinen säädeltävä hyödyke. Isät saavat synnytykseen vaimennusoppia, muuten syntymisen ihme saattaisi jäädä kokematta, kesäyliopisto järjestää kuolemansuruseminaarin, muuten suru jäisi surematta.

Uusromantikoksi moitittu Ivan Illich kritisoi tätä oppia voimakkaasti. Se invalidisoi ihmisen psyykkisesti, vie häneltä rohkeuden ja aloitekyvyn ja tekee hänestä passiivisen palvelujen kuluttajan ja uusien vaatijan. Illich vaatiikin koulujen lakkauttamista ja koko yhteiskunnan opinnollistamista: mahdollisuutta tiedon ja taitotiedon hankkimiseen niiden synty- ja varastointipaikoilla, museoissa, kirjastoissa, teattereissa, taidenäyttelyissä, työpaikoilla, kansalaisforumeilla.

\section{TEESI: Voimavarojen säästämiseksi on purettava koulutuksen segmentointi ikäluokkien, maksajan tai asiaksryhmien mukaan sekä yhdistettävä päällekkäisiä organisaatioita. Tieto ja osaaminen eivät karsinoidu.}

Organisoitu oppiminen lieneekin tulevaisuuden sivistys-Suomessa lähempänä Illichin kuin konsensusmallia. Pakottajana ei ole vain ehtyvä julkinen talous, vaan myös yhteiskunnan ja perheen muuttuminen, joiden kuva oppilaitos aina on ollut.

Modernissa yhteiskunnassa yksilö ja hänen järkensä olivat ylin auktoriteetti. Ne loivat suuria kertomuksia, joiden ohjaamalla uskolla universaaleihin ja säännönmukaisuuksiin rakennettiin edistystä. Postmoderni siirtyy ajatuksesta kieleen, yksilöstä monimuotoisuuteen. Kieli ei edisty, se rakentaa todellisuuden paikallisiksi ja tapauskohtaisiksi tietämysalueiksi. Se pitää yllä säännöttömyyttä ja eriytyneisyyttä.

Perhe on jo kokenut rakenteellisen muutoksen. Parisuhteen perustasta, romanttisesta rakkaudesta on siirrytty sopimusrakkauteen, biologisesta vanhemmuudesta jaettuun ja hajautettuun van- 
hemmuuteen, staattisesta olemisen muodosta urbaanisiin arvoihin ja elämätapoihin. Lapsuus ja nuoruus nähdään jo elämäänsä hallitsevien "pienoisaikuisten" elämänvaiheena, koska tekninen vanhemmuus tarvitsee kompetentit lapset ja sofistikoituneen nuorison. Rajat työn ja vapaa-ajan, kodin ja opiskelun, yksityisen ja julkisen, lapsuuden ja aikuisuuden välillä ohenevat.

Oppilaitokset omaksuvat uuden perheen arvot. Ne ovat vain yksi tilkku opiskelijan tilkkutäkissä, maailmassa jossa Luther sanoisi: "Tässä seison, mutta voisin minä jotakin muutakin tehdä. "

On vaara, että eriytymisen ja hajoamisen seurauksena asiantuntemus kapenee, kokonaisnäkemys katoaa ja sen tuloksena vastuu osittuu tyhjäksi fraasiksi. Yliopisto on ollut osasyyllinen kehitykseen salliessaan ja rohkaistessaan tieteen balkanisoitumista.

\section{TEESI: Edessä on väistämättä korkeimman koulutuksen voimakas moni- ja yhteistieteinen eheyttäminen, sillä yhteiskunnan ongelmat eivät sektoroidu eikä asiantuntemus jakaannu tiedekartan mukaisesti.}

Integrointi voi tapahtua ideologisesti niin kuin naistutkimuksessa tai rauhantutkimuksessa on tapahtunut, ongelmakeskeisesti (ympäristö- ja kehitystutkimus), työelämäkeskeisesti (terveydenhuollon ja sosiaalityön integrointi) tai tiedeperusteisesti ryhmittämällä sukulaistieteet uusiksi kokonaisuuksiksi (informaatiotieteet). Koulun opetussuunnitelmaa on hallinnut 200 vuotta kokoomakoodi (Bernstein) ja yliopisto-opetusta oppituolikeskeisyys maailman muuttumisesta piittaamatta.

Koulutuksen alisteisuudesta seuraa, että koulutusreformit jatkuvat kiihtyvällä nopeudella. Koulutuksesta on näet helppo tehdä syntipukki yhteiskunnan patologialle. Truistisena itsestäänselvyytenä se on oiva, puolustuskyvytön maali, josta puhuttaessa jokainen on asiantuntija. Syyttämällä koulutusta voidaan silmät ummistaa yhteiskunnan rakenteellisilta epäoikeudenmukaisuuksilta, työelämän jähmeydeltä ja korporaatioiden vallanhimolta. Koulutuksen rakennetta ja sisältöä on helppo vaatia muutettavaksi puuttumatta sen ja yhteiskunnan konstitutionaaliseen suhteeseen. Vaikka Torsten Husen onkin todennut, että koulu ei voi kompensoida muuta yhteiskuntaa, kulttuurin rakennusosana sillä on keskeinen merkitys, kunhan muistetaan, että koulutettu ei välttämättä ole oppinut eikä oppinut ole vielä sivistynyt ja että ihmisen arvo mitataan muutenkin kuin häneen tehtyjen investointien tuottoasteena.

Formaalisen koulutuksen monopoli informaation vartijana murtuu väistämättä. Opettajien määrää vähennetään radikaalisti kaikilla koulutusasteilla (jos koulutusasteajattelu ylipäätänsä säilyy) ja heidän tehtävistään osan suorittavat koulun sidosryhmät vapaaehtoistyönä tai halvempana aputyönä. Työelämä ja koulutuslaitokset solmivat koulutussopimuksia, koska yrityksille tulee edullisemmaksi osallistua työntekijöiden peruskoulutuksen kustannuksiin kuin tulokoulututtaa heidät välittömästi uudelleen yritykseen rekrytoitaessa.

Uudelleen harkittavaksi tulee myös tapa liittää työ ja koulutus toisiinsa. Yhä järkevämmältä tuntuu vaihtoehto, että oppivelvollisuuskoulun ja työelämään perehdyttämisen jälkeen nuori sijoittuu työhön. Näin hän etsii itseään kiinnostavan alan, hankkii siinä oppisopimuskoulutuksella ammattimiehen perusvalmiudet, joita täydentää ja systematisoi myöhemmin muodollisella koulutuksella. Työntekijälle annetaan siis mahdollisuus ensin valita koulutusala ja myöhemmin elinikäisen koulutuksen järjestelmää hyödyntäen päättää koulutusasteestaan. 
Englannissa erään koulutuskomitean puheenjohtaja esitti, että jo 10 - 15 vuotta koulua käyneelle kahden vuoden mittainen korkeakoulututkinto on useimpiin professionaalisiin ammatteihin aivan riittävä perusta.

Koulutuspoliittiset tavoitteet realisoituvat vasta pitkällä aikavälillä. Tarvitaan siis tulevaisuuden tarpeiden, yhtä hyvin kysyntä- kuin tarjontatekijöiden ja koulutuksen yhteiskunnallisen kontekstin ennakointia. Tulevaisuuden polkujen valinta edellyttää kuitenkin riittävää kansallista ja kansainvälistä yksimielisyyttä tavoitteista.

\section{TEESI. Koulutusjärjestelmän ennakointikyvyn parantamiseksi tarvitaan kahden} järjestelmän työn tarkastelua rinnakkain: toinen on poliittisia valintoja tekevä arvojärjestelmä ja toinen tekninen, ennusteita ja kehityskulkuja kartoittava informaatiojärjestelmä.

Koulutussuunnittelun alan on laajennuttava määrällisestä työvoimatarpeen ennakoinnista systemaattisen ja kumuloivan oppimisjärjestelmän ja sen responsiivisuuden ennakoinniksi. julkisen vallan ylläpitämä ja valvoma koulutusjärjestelmän ydin on tarpeen sirpaloituvassa kaikki kelpaa -maailmassa, vaikka kustannus- ja organisointivastuu jaetaankin uudella tavalla.

Säätytalo 21.11.1995 